Intergovernmental Oceanographic Commission technical series

\title{
Manual on international oceanographic data exchange
}


Publisbed in 1965 by the United Nations Educational. Scientific and Cultural Organization, place de Fontenoy, Paris-7e

Composed in Unesco's workshops

Printed by IFMRP, Paris

The designations employed and the presentation of the material in this publication do not imply the expression of any opinion whatsoever on the part of the Secretariats of Unesco and IOC concerning the legal status of any country or territory, or of its authorities, or concerning the delimitations of the frontiers of any country or territory. 
Introduotion .............. 5

Part I IOC Resolution III-11 on Exchange

of Oceanographic Data ..........

Part II Provisional Guide for Exchange of

Oceanographic Data .......

Part III Recommendations of the IOC Working Group on Exchange of Oceanographic

Data

Paxt IV List of National Oceanographic Data

Centres or Designated National

Agencies, and information concern-

ing their mode of operation ........

Appendix I Extracts from the CIG "Guide to International Data Exchange through the World Data Centres (for the period 1960 onwards)". . . . . . . . . 
The purpose of this manual (see Part I), is to assemble in convenient form for the guidance and use of practising oceanographers the various documents concerned with the assembly and disssemination of oceanographic data of all kinds. The full and expeditious exchange of data is the core of meaningful scientific co-operation. Investigations of phenomena and processes of global dimensions, such as those occurring in the ocean and atmosphere, are particularly dependent on the pooling of data from various sources.

A system for exchanging oceanographic data on a regional basis has been operated successfully for many years by the International Council for the Exploration of the Sea. The programme of the International Geophysical Year made necessary the creation of a world-wide system. Thus World Data Centres $A$ and $B$ (Oceanography) were established in Washington and Moscow, their operations being financed by the United States and the USSR. These centres, together with those in other disciplines, are responsible to the International Geophysical Committee (CIG) of the International Council of Scientific Unions (see Appendix I to the manual).

The Intergovernmental Oceanographic Commission has produced a "Provisional Guide for Exchange of Oceanographic Data" (Part II of this manual). While the terms of the Provisional Guide are voluntary, it should be recognized that order is necessary in such a rapidly expanding science if the full advantages of this expansion are to be widely realized in the most efficient way. Approximate time limits as well as methods for the submission of the various kinds of data remain therefore a feature of the revised Guide, although a less exacting one than before.

The "Provisional Guide for Exchange of Oceanographic Data" is supplemented in this manual by recommendations of the IOC Working Group on Oceanographic Data Exchange (Part III) adopted in January 1964 and approved by the Commission at its third session. These recommendations give details which are not conveniently included in the Provisional Guide itself.

World Data Centres will in due course receive oceanographic data, in accordance with the Provisional Guide for declared national, or international oceanographic programmes. Such programmes entail an obligation to send data to the WDCs. Data can be sent to WDCs by laboratories or other data centres. Part IV of the manual is a list of existing or projected national oceanographic data centres or other designated national agencies, with their addresses, methods of working, and, where applicable, the services offered by each to data contributors.

The oceanographic data exchange system exists to facilitate the prosecution of marine research. Its success depends on the support of oceanographers, their supply and use of oceanographic data, and their suggestions for making the system responsive to their needs. 
RESOLUTION III-11

EXCHANGE OF OCEANOGRAPHIC DATA

The Intergovernmental Oceanographic Commission

Desiring to foster the full and expeditious exchange of oceanographic data,

Recognizing that this desire is closely related to the intention of IOC members to co-operate in joint scientific study of the oceans,

Recognizing further that this intention expresses itself either in participation of IOC members in international co-operative expeditions or in declaring publicly their own national oceanographic programmes with a view to exchanging data resulting therefrom,

Recognizing the special interest of members in the organization and operation of World Data Centres and specialized and regional centres for the collection and exchange of oceanographic data, in accordance with the principles of equality of rights and mutual assistance,

Resolves

(1) To approve the new text of the Provisional Guide for Exchange of Oceanographic Data as prepared by the IOC Working Group in cooperation with SCOR;

(2) To submit it for inclusion into the General CIG Guide to International Data Exchange through the World Data Centres; and

(3) To keep it under constant review by the Commission's working group in co-operation and consultation with SCOR and ACMRR.

Recommends that all scientific data originating from "declared national oceanographic programmes" and "international co-operative oceanographic expeditions" (as defined in the above Provisional Guide), comprising results of observations and measurements by ships and recording stations outside territorial waters, as well as sea level observations, be exchanged by the methods and under the definitions and spectfications prescribed in the above Provisional Guide for Exchange of Oceanographic Data, commencing with 1 January 1960 .

Recommends that in view of the great scientific value of long time series records, mean sea level observations should be reported back to the time of establishment of the gauge wherever practicable,

Resolves that upon acceptance by CIG, the principal documents regulating the exchange of oceanographic data between members will be the present resolution, the Provisional Guide for Exchange of Oceanographic Data approved herein, the introduction and general sections of the CIG Guide to International Data Exchange, and associated recommendations of the Commission's Working Group on Oceanographic Data Exchange.

Instructs the Secretary to prepare and distribute widely a manual on international oceanographic data exchange which will include the documents mentioned in the preceding paragraph, lists of national and specialized oceanographic data centres together with their addresses, methods of operation and services and facillties avallable, and such other information as will be useful in facilitating the full and expeditious exchange of oceanographic data,

Recommends that the Commission, through its Secretary, communicate the present resolution and associated documents to the CIG, at the same time indicating its desire to be represented on that body. 
PART II

PROVISIONAL GUIDE FOR EXCHANGE OF OCEANOGRAPHIC DATA

1. World Data Centres

Oceanography

A. World Data Centre A

Oceanography

Washington, D.C.

U.S.A. 20390

B. World Data Centre B

Oceanography

Molodezhnaya 3

Moscow B-296

USSR

2. Specialized Centres

\subsection{Disciplinary}
2.1.1 The Permanent Service for Mean Sea Level
The Observatory
Birkenhead, England.

2.1.2 International Hydrographic Bureau

Monte Carlo, Monaco.

\subsection{Regional}

\subsubsection{International Council for the Exploration of the Sea \\ Charlottenlund Slot \\ Charlottenlund, Denmark.}

\section{Oceanographic Programmes}

\subsection{Declared national programmes}

An important form of international co-operation in oceanography is the public declaration by an IOC member of the whole or parts of its oceanographic activities, with the implied intention to exchange internationally data resulting therefrom. Such "declared" national programmes are communicated to the IOC Secretariat with a statement of declaration and resulting data should be exchanged in accordance with provisions of this Guide.

\subsection{International co-operative expeditions}

Another important form of international co-operation in marine sciences is participation in an international co-operative oceanographic expedition. The agreement to conduct such an expedition jointly is naturally associated with an intention on the part of participating countries to share its results. When such an expedition is carried out under the auspices of the IOC the resulting data enter automatically the exchange system outlined in this Guide: in addition, special features of the exchange may be established by an 
appropriate international co-ordination group. If, however, such an expedition is organized by other intergovernmental or non-governmental organizations, pertinent data may enter the present scheme of data exchange elther through regional and specialized centres (see 6.4.1) or through declared national programmes as regards IOC members participating in such an expedition.

\subsection{Other oceanographic programmes}

Countries not members of IOC, conducting oceanographic programmes of international interest, are encouraged to exchange oceanographic data through the World Data Centre system in accordance with provisions of this Guide.

\section{Types of observations and description of data}

\subsection{Standard observations}

These are environmental observations or measurements made from oceanographic ships, other mobile platforms, shore or fixed stations (except moored buoys) with generally accepted types of instruments and methods widely known and described in scientific literature. Data of this classification, when submitted for general use, either require no further correction, or the corrections are well known and generally available. Data resulting from these observations or measurements should be exchanged through the World and Specialized Data Centres System according to the principles specified in Sections 5 and 6.

The following are the major kinds of standard oceanographic and marine meteorological data recorded in connexion with oceanographic programmes:

4.1.1 Values of air temperature, ocean surface temperature, atmospheric pressure, humidity, speed and direction of wind, precipitation and visual observations of cloud cover and weather, visibility, sea ice and other atmospheric phenomena recorded at standard hours.

4.1.2 Visual observations of sea and swell (scale numbers and/or estimated directions, heights and periods).

4.1.3 Colour and transparency values by Secchi disc.

4.1.4 Soundings either on plotting sheets or in tabulation.

4.1.5 Values of temperature, salinity (or its measures) and chemical properties at surface and at depth, including mean monthly and annual values for shore and fixed stations and continuous records such as bathythermogrammes.

4.1.6 Mean monthly and annual sea levels computed from hourly observations from a recording gauge or alternatively according to standard observations on a tide staff.

4.1.7 Information on bottom samples:

Cores: length, short, qualitative description. Where possible, estimates of the probable age of top and bottom parts are especially desirable.

Other samples: short qualitative description.

4.1.8 Values of routine primary production, chlorophyll, phytoplankton biomass, zooplankton biomass and benthos biomass measurements. (With an understanding that efforts to standardize existing methods or to make comparable results of their application will continue till satisfactory results are achieved).

4.1.9 Upper air data from oceanographic vessels: air temperature, humidity, pressure and speed and direction of wind at various heights.

The above standard observations make part of both "declared national programmes" and international co-operative expeditions. It is understood that in the latter case other types of less standardized observations (e.g . current measurements) might be included in the above list by international co-ordinating groups when these expeditions make such observations on a routine basis. It is also understood that the above list does not prevent originating countries from sending in to World Data Centres and Specialized Centres other 
types of data which might correspond to the general definition of standard observations.

\subsection{Non-standard and experimental observations}

These cover all observations and measurements made by devices and instruments of experimental types or in accordance with experimental procedures; observations and measurements made for specific research projects and those observations which, due to their nature and volume, can be processed only by elaborate computing or analytical techniques.

Data resulting from these observations or measurements are generally to be retained by originating countries and exchanged directly upon requests according to the principles specified in 5 and 6 . It is desirable for originating countries to report to World Data Centres and/or Specialized Centres information on the availability and sources of these data.

No detailed specification for such kinds of observations and resulting data is needed. The following list serves only to exemplify some of them:

4.2.1 Instrumental measurements of various physical (optical, acoustic, electric, etc.) properties of sea water including those from moored buoys.

4.2.2 Results of chemical analysis of trace elements.

4.2.3 Instrumental measurements of waves and swell, including long waves observations and recordings.

4.2.4 All kinds of current measurements and studies of turbulence (e.g. velocity spectra). Continuous recordings of currents from moored buoys.

4.2.5 Bottom photographs, topographic profiles, interim bathymetric charts, biochemical analyses, etc.

4.2.6 Gravity and geomagnetic fleld measurements, heat flow, seismic refraction and reflection observations, etc.

4.2.7 Specialized meteorological observations: solar radiation, gradient measurements of wind velocity, temperature, humidity, etc. Meteorological recordings from moored buoys.

4.2.8 Specialized biological studies and samplings: collections for systematic studies, microbiology, etc.

\section{Supplementary information and form of presertation required}

\section{1}

Each submitted record should contain the date, time, position, depth at station and the name of the observing ship or station. Records from shore and fixed stations carrying out regular observations should contain hours of these regular observations. The time in use is to be stated, e.g. GMT or zone time. In case of a considerable drift of the vessel, positions at the beginning and at the end of stations are required. Estimates of precision of positions, and navigational methods used, should be reported.

\section{2}

Instrumental corrections should always be made before the data are submitted.

5.3

Metric units and Celsius scale should generally be used.

5.4

Relevant details of instruments and methods used and estimates of precision are required for all kinds of oceanographic data. 
5.5

Specific requirements as to the supplementary information and form of presentation are listed below under sub-divisions corresponding to those given under 4.1 and quoted in parenthesis:

5.5.1 (4.1.1) WMO code should be used for reporting wherever practicable. If other cudes are used, they should be specified.

$5.5 .2(4.1 .2) \quad$ Scale used should be specified.

5.5.3 $(4,1.3)$ Size of the disc and colour scale should be specified.

5.5.4 (4.1.4) The following specific information is required:

(a) The make and type of echo-sounder used;

(b) Value of the velocity of sound at which the apparatus is calibrated;

(c) Corrections (i.e. which functions if any) applied;

(d) All fixes, together with their times and dates;

(e) Estimated accuracy of fixing methods in use.

5.5.5 (4.1.5) It is preferable that these data be submitted on forms facilitating machine processing or on punched cards (together with the punching code used). Estimates of accuracy and/or precision of measurements should be included if possible. In the case of deep water casts the time of the observation is that of dropping the messenger. Wire angle should be reported in all cases; information on the number of unprotected thermometers and their disposition in depth is desirable. Literature references for chemical methods used are desirable in addition to simple citation of the method. On BT records the temperature reference point should be indicated.

5.5.6 (4.1.6) Additional details of installation and method of reduction of data will be sought as necessary by the Permanent Service for Mean Sea Level.

5.5.7 (4.1.7) Types and sizes of instruments used should be indicated. If codes are used for qualitative description of samples, they should be specified. The address where samples are stored should be reported.

5.5.8 (4.1.8) The following specific information is desirable where appropriate:

(a) Local time of sunrise and sunset.

(b) Time of commencement and completion of each operation.

(c) Type and depth of sampling.

(d) Specification of gear and/or method used.

(e) Address at which samples are stored.

(f) Literature references to methods used.

$5.5 .9(4.1 .9)$ WMO format is to be used.

6. Transmission of data

The transmission of data to data centres should, as far as possible, conform to the following principles:

6.1

Observational data from shore and fixed sțations should be dispatched without delay, preferably not more than one to two months after the period of observations.

6.2

In respect of cruise data, the first step should be to send within about three months a preliminary report of the cruise, showing station positions, types of observations and a list of scientists concerned. Alternatively, at least a list of station positions with the work done at each may be sent within this interval. 
Cruise data should be forwarded as expeditiously as possible after the completion of the cruise. For temperature and salinity data the interval should not normally exceed nine months. Chemical, biological and geological data may require a slightly longer interval which should not however exceed one year. When biological collections for later systematic studies are made on a cruise, details of the hauls made (the same as in Section 5.5 .8 ) should be submitted along with the temperature and salinity data.

\section{4}

Except as noted below, data should be sent to both WDC-A and WDC-B, either directly or via one of these centres or via a regional centre. The method of distribution adopted.should be indicated on the transmittal letter accompanying the data. For information, copies of the transmittal letter should be sent to other centres.

6.4.1 Mean sea level data (4.1.6) should be sent to the Permanent Service for Mean Sea Level $(2.1 .1)$ and soundings $(4.1 .4)$ either in the form of plotting sheets or in tabulations, to the International Hydrographic Bureau (2.1.2) or to any qualified hydrographic office. In the case of regional centres, such as ICES (2.2.1), established practices should continue, regional centres having the further obligation of sending the data to the World Data Centres.

6.4.2 Copies of all meteorological observations including upper air observations, as listed under 4.1.1,4.1.2 and 4.1.9 should be sent to the National Meteorological Services concerned with the request that - besides being handled as prescribed for marine meteorological observations in general - they should be sent also to the World Data Centres for Oceanography.

\section{5}

For cataloguing non-standard and experimental data (Section 4.2 ) which are being retained by originatIng countries, these countries should send to World Data Centres identifying indices (position, time of collection, nature of observation or measurement and location of the data) at the same time as standard data.

\section{6}

To obtain non-standard and experimental data falling within the general definition given under 4.2 and resulting from "declared" national programmes, interested institutions or individuals may apply to a source of data in the originating country. Generally data in question can be released at cost of reproduction or in exchange for equivalent data suggested by the requesting side. Similar data resulting from co-operative investigations should be exchanged in accordance with procedures worked out by corresponding international co-ordinating groups.

\section{Collection of publications}

National Data Centres or appropriate national agencies are requested to send to each of the World Data Centres one copy of each national scientific publication dealing with the quality and applicability of data held in the centre. World Data Centres, however, should be free to acquire by exchange, subscription or other means, all kinds of scientific literature considered necessary for their operation. 
RECOMMENDATIONS OF THE IOC WORKING GROUP ON OCEANOGRAPHIC DATA EXCHANGE (as approved by the Commission at its 3rd session, June 1964)

The Working Group reaffirmed earlier recommendations concerning the Importance of national data centres as focal points for the submission of data to the World Data Centres, and noted that such national centres, workdng closely with participating national laboratorles and institutions, were the appropriate bodies to ensure that data entering the World Data Centre system are of the highest possible accuracy.

The Working Group recognized that responsibility for the quality of data entering the World Data Centre syetem rests with the originating bodies, not with the World Date Centres. However, the World Data Centres can provide a valuable service to international oceanography by monitoring the quality of incoming data and advising originating governments of any errors so detected. It is recommended that the assistance of SCOR, ACMRR, and other appropriate advisory bodies should be sought to establish technical spectfications for data quality.

- Examination of the agenda item concerning problems of communication with ICES and other specialized data centres revealed that recent negotiations between these centres and the World Data Centres had largely eliminated such problems. It was agreed that permanent regional data centres and national data centres serving temporarily as regional centres in connexion with international co-operative investigations, have a responsibility to make such regional data collections available to the World Data Centres.

It was noted that many IOC members had not submitted declared national programmes, and that not all programmes submitted had been identified as "declared". In the sense of resolution 9, first session of the IOC, the implication of a declared national programme is that, through the World Data Centres and in accordance with the terms of the Guide for Oceanographic Data Exchange, the data accruing from such programmes should be made available for exchange.

It is recommended therefore that members should be urged to submit such information promptly, preferably in the standard format used in the quarterly newsletter International Marine Science.

It is further recommended that declared national programmes should, as a whole or in appropriate parts, be identified by a distinctive suffix, such as for instance DNP, which could be entered in the "Comments" column of Section $C$ in International Marine Science.

Additionally, it is recommended that the Secretarlat should if possible ascertain whether programmes already submitted are in fact "declared" for the purposes of data exchange, so that a definitive list of declared programmes can be maintained, such a list being necessary for the planning of work at the World Data Centres.

It was constdered that the submission of data to the WDCs should take place in a progressive sequence as follows:

1. Declaration of national programmes (see above).

2. Submission of preliminary reports soon after completion of cruises, showing positions and types of observations, lists of scientists concerned, and, where possible, preliminary results of the cruise.

3. Submission of data and indices of observations. These indices should include necessary information on observations being retalned by the originating government, for inclusion in the WDC catalogues.

4. Exchange of scientific publications resulting from work at sea.

In considering the problem of the speedy utilization of oceanographic data, the Working Group recognized that synoptic oceanographic services were already functioning on a national or regional basis in a few cases. Further experience with such restricted programmes is required before an effective international programme can be designed. Consideration of the problem by a working group of the ACMRR is expected to contribute to a better understanding of the problem as well as to that of the desirability or otherwise of 
including fishery statistics amongst the data to be submitted to the World Data Centres.

It was agreed that the primary responsibility of World Data Centres is the collection and distribution of data and that responsibility for the processing of oceanographic data should be at the national level. If contributors of data require assistance in processing, arrangements may be made through a World Data Centre or appropriate national data centre, terms being established by agreement. It was recc data on standard forms, as recommended in the Provisional Guide, would facilitate machine processing of such data.

It was considered necessary to give, as a part of this report, the following statement on exchange of biological data which was prepared by a group of marine biologists present at the meeting.

\section{"Exchange of biological data}

The Working Group considered that a minimum requirement should be to submit along with physical and chemical data, details of what biological sampling was done. This information should include if possible: position, date, time zone, local time of sunrise and sunset, sounding, and the type of sampling (that is phytoplankton, zooplankton or benthos sampling, midwater trawling, long lining or other forms of fishing, underwater photography, acoustic studies, surface collections, etc.) or measurements (primary production, optical measurements, etc.). Details of the sampling should also be included, incorporating information about the type of gear used, the times of commencement and completion of sampling and the upper and lower depth of sampling, etc. It should also be stated where further information concerning the samples or measurements can be obtained.

Biological results, on the other hand, can be divided into a number of categories which lend themselves in varying degrees to handling by data centres. Many come under the heading of 'information retrieval', including systematic or taxonomic information, descriptions of organisms, publications, etc. and these present particularly difficult problems . Other data are insufficiently uniform with regard to method or take the form of continuous records which are difficult to handle. Sorre biomass statistics are already included in specialized data centres.

The Working Group feel, therefore, that the categories of biological results which can usefully be handled by data centres at the present time are the following:

1. Primary production measurements

2. Chlorophylls
3. Phytoplankton biomass

4. Zooplankton biomass

5. Benthos biomass

The submission of such data in any form is acceptable providing they are accompanied by precise details of the methods used. It is hoped that after consideration by specialized working groups of SCOR, ACMRR, etc. and as a result of the standardization and intercalibration work being conducted by SCOR and other bodies it may eventually be possible to reach agreement on standardized reporting. As methods improve in the future it will become desirable to include other biological observations, in particular those which may be of importance in fishery oceanography".

Previous recommendations of the working group (NS/180, Annex VI) were reviewed. Of those which have not yet been fully implemented, the following were considered to require further emphasis or clarification:

1. Declared national programmes should include those shore and fixed stations reported to the Secretariat for their compilation of the existing network of such stations. Changes in declared national programmes should be submitted annually to the Secretariat.

2. Mean sea level observations should be reported back to the time of establishment of the gauge wherever practicable, in view of the great scientific value of long time series records of such observations. It is not considered necessary that mean sea level data deposited in the Permanent Service for Mean Sea Level should also be deposited in the World Data Centres.

3. World Data Centres A and B should proceed promptly with their preparation of a revised format and schedule for future catalogues of their holdings. It was suggested that the centres should also study the possibility of compiling and publishing a bibliography of the sources of historical (preIGY) oceanographic data.

4. The proposal for early submission of provisional data was not considered by the Working Group to be practicable except in the case of cooperative investigations, where special requirements were established by the International Coordinating Group.

It was recommended that appropriate steps be taken, in consultation with WMO, to ensure that synoptic meteorological data from ocean island stations be deposited in the appropriate World Data Centres.

The Working Group recognized that for continuity in the exchange of oceanographic data, it was essential that members continue to exchange such data under the present Provisional Guide until such time as a revised guide is officially adopted. 
PROVISIONAL LIST OF NATIONAL OCEANOGRAPHIC DATA CENTRES (NODC) OR DESIGNATED NATIONAL AGENCIES (DNA)

\author{
a - established \\ b - about to be established \\ c - under consideration \\ - does not exist \\ ? - no information received
}

Table 1

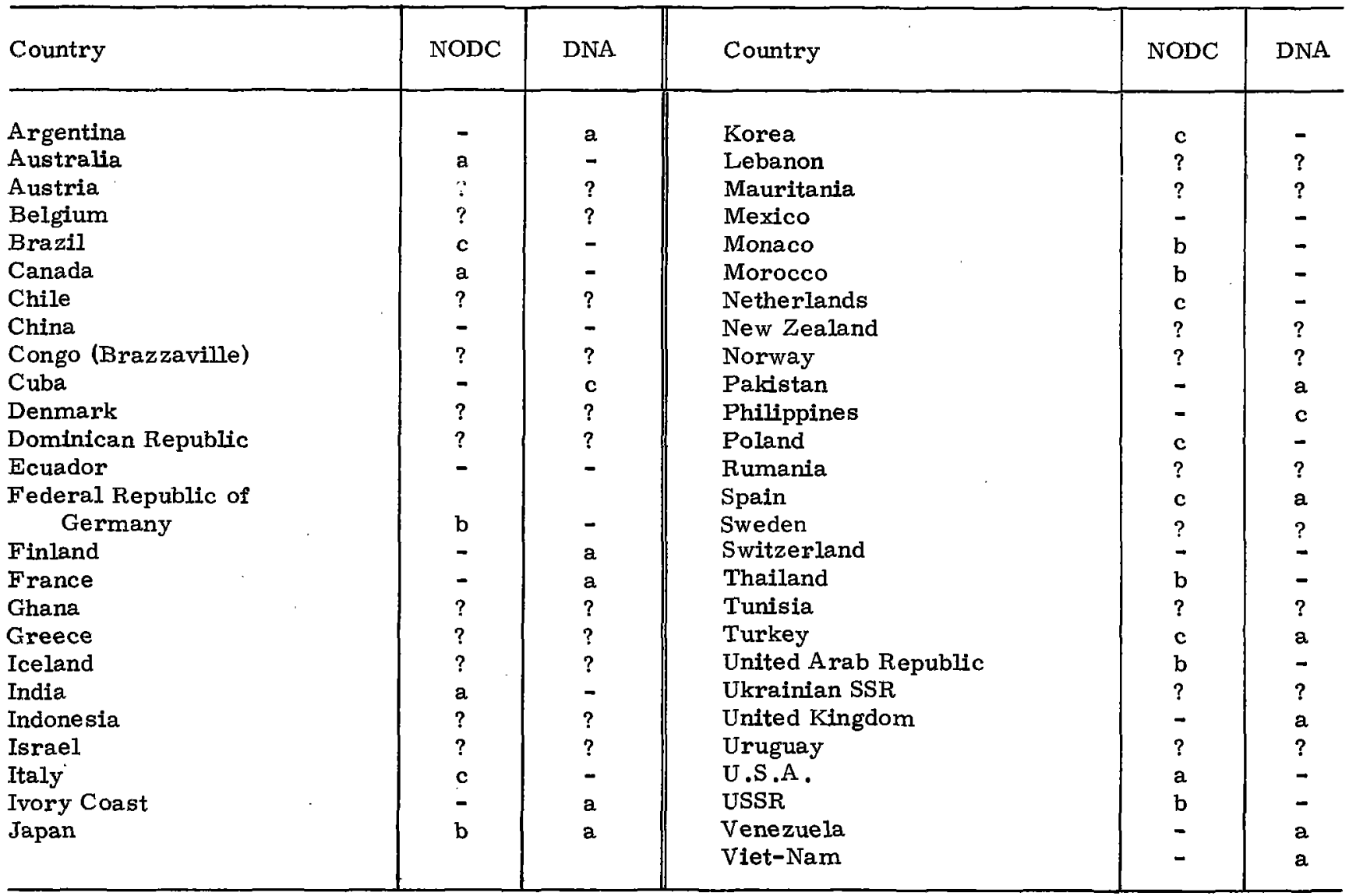

This list is compiled on the basis of oral information given by delegates at the meeting of the IOC Working Group on Oceanographic Data Exchange (January 1964) and subsequently confirmed by answers to the IOC Circular Letter CL-71 of 17 August 1964. Addresses of existing Natlonal Oceanographic Data Centres and Designated National Agencies as well as information on their mode of operation are given in Table 2 and subsequent pages. Quite a number of the IOC members have not yet answered Circular Letter no.71 and therefore a question mark appears against the names of such countries, both for NODC and DNA. The Secretariat considered that the publication of this manual could not be delayed further. 
Addresses of National Oceanographic Data Centres or designated agencies already in existence

Table 2

\section{Country}

National Oceanographic Data Centres

1. Argentina

2. Australia

3. Canada

4. Finland

5. France

6. India

7. Ivory Coast

8. Japan

9. Rakistan

10. Spain

11. Turkey

12. United Kingdom

13. United States

18
Australian Oceanographic Data Centre, Hydrographic Office, Garden Island, Sydney

Canadian Oceanographic Data Centre, 615 Booth Street, Ottawa.

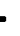

National Oceanographic Data Agency, Directorate of the Indian Ocean Expedition B-7, Hauzkhas Enclave. New Delhi, 16.

National Oceanographic Data Center, Washington, D.C . 20390.
Designated national agencies

Naval Hydrographic Office, A venida Montes de Oca, 2124, Buenos Aires

Institute of Marine Research, Merentutlimuslaitos, Helsinkd 4, Finiand

M. Gougenheim, Service Hydrographique, 13 rue del'Universite, Paria VIIe.

Centre de Recherches Ocsanographiques, B.P. 35, Abidjan.

Science Section, Japanese National Commission for Unesco, 4 Kasumigaseki, 3-chome, Chioda-ku, Tokyo.

Director, Meteorological Services, Government of Pakistan, Karachi.

Instituto Espanol de Oceanographia Alcala 27, Madrid.

Turkdeh Navigational and Hydrographic Department, Gubuklu, Istanbul.

Hydrographer of the Navy, Oxgate Lane, Cricklewood, N.W.2, London. 
14. Viet-Nam

15. Venezuela
Institut Oceanographique, Canda, Nhatrang.

Oceanographic Institute of the University of Oriente Cumana, Estado Sucre.

\section{ARGENTINA (translated from Spanish)}

"... . . Our Service of Naval Hydrography acts. in fact with the equivalent functions as a National Centre of Oceanographic Data, as it compiles, classifies, estimates and preserves the oceanographic data which are obtained in the cruises of its research vessels, including cruises corresponding to declared national programmes and cooperative expeditions as well (Tridente, Equalant, etc.)........ Aforementioned information is interchanged with the World Data Centres and provided to national or foreign institutions which require them....."

\section{AUSTRALIA}

".......Australia has one oceanographic data centre and it is located in the Hydrographic Office. All requests for Australian data should be sent to the Director, Australian Oceanographic Data Centre, Hydrographic Office, Garden Island, Sydney. On request, the Director will send copies of data, of punched cards, or of publications containing data, to other data centres, international organizations, laboratories, departments and similar bodies. Some special processing can be done. If any charge is to be made, the Director will advise the requesting body before dispatch. No data catalogues are prepared".

\section{CANADA}

\section{(a) Name and address of national data centre}

Canadian Oceanographic Data Centre(1), 615 Booth Street, Ottawa.
Mode of operation of NODCs and DNAs (extracts from letters from governments in response to the IOC circular letter CL-71 of 17 August 1964)

\section{(b) Method of operation}

The Canadian Oceanographic Data Centre is located under the Marine Sciences Branch of the Department of Mines and Technical Surveys. Guidance in establishing policies regarding its scientific and technical operation is being solicited from all member agencies of the Canadian Committee on Oceanography. The attached chart depicts the organizational layout of the Data Centre.

Methods of operation pertaining specifically to the treatment of physiochemical data have been described in detail in CODC 's "Oceanographic Data Processing Manual", a copy of which has been enclosed.

The routine processing described in this manual may be divided into the following well-defined steps :

1. Receipt of cruise notification form.

2. Preparatory steps in anticipation of data submission.

3. Recelpt of data.

4. Assessment of data entries.

5. Key-punching.

6. Verification.

7. Line-proofing and corrective action.

8. Computation on IBM 1620 II.

9. Return to originator of preliminary computer output (IBM 1401 Automatic Report Generator Programme).

10. Storage of output (punched cards) on cruise file.

11. Preparation of data for international exchange.

12. Correction control action.

(1) CODC also has the temporary status of a regional centre (Specialized Oceanographic Data Centres) in support of ICNAF' is NORWESTLANT Surveys. 
13. Preparation of data record of publication. 14. Storage of data on magnetic tape, sorting and merging for up-dating of the geographical data files.

Step 13 also includes information on all other types of oceanographic data collected on the cruise.

\section{(c) Services and facilities available}

The Canadian Oceanographic Data Centre provides its services at no cost to all member agencies of the Canadian Committee on Oceanography. In doing so it will:

receive, compile, process and preserve appropriate oceanographic data provided to it;

be responsible for acquiring by exchange, or otherwise, data of scientific value from domestic and foreign sources;

establish procedures and routines to ensure that the accuracy and general quality of the material meets the criteria to be established by a CCO Advisory Council on Data Processing. and undertake analytical studies required for this purpose prior to incorporating the data in its holdings;

prepare and distribute its processed holdings originating from member organizations as data records, print-outs, magnetic tape, punch cards or in any other form, as required;

on request, prepare summaries of any part of its holdings, prepare statistical summaries of annual and/or seasonal oceanographic conditions in the areas of immediate Canadian interest;

prepare at regular intervals indexes of its holdings for distribution to member organizations;

promote systematic collection of routline oceanographic data for time series studies;

act as Canada's official agency for the international exchange of oceanographic data.

\section{Facilities}

(a) Computers:

IBM-1620 mode1 II for most routine work. IBM-7074 for magnetic tape work.

Access to any of a wide variety of government owned computers in the Ottawa area for special projects.

(b) Unit record equipment:

Complete tabulating equipment, including sorters, listing devices (on-line and offline), key punches, veriflers, collators, reproducers, interpreters, etc.

(c) Automatic plotters:

(i) On-line: IBM-1627

(ii) Off-line: EAI (d) Completa microfllm equipment for bathythermograph data processing.

(e) Telex communications facilities.

ORGANIZATION CHAR'T

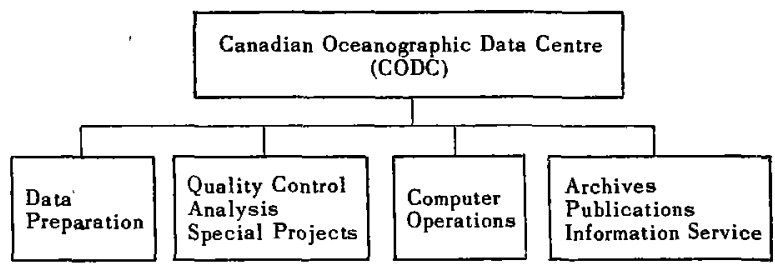

FINLAND

"...... the Institute of Marine Research, Merentutkimuslaitos, Helsinki 4, Finland, is acting as national data centre for Finland. All relevant data, collected by the Finnish marine scientists, on hydrography, marine chemistry, air chemistry, sea level changes of the Baltic, ice observations of the Baltic, and on plankton and benthos are stored in the said Institute and can be made available. Main part of the data are delivered already to the international data centres".

FRANCE (translated from French)

"...... There exist in person of Mr. Gougenheim, Ingenieur genéral hydrographe, an intermediary who, being assisted by the Committee on Oceanography and Coastal Studies and enjoying facilities of the computational office of the Hydrographic Service, is charged with transmission of all the data received from different sources or the Institute of Oceanography to either International Council for the Exploration of the Sea or the World Data Centres in Washington and Moscow directly. The office of $\mathrm{Mr}$. Gougenheim is located at the headquarters of the Hydrographic Service, 13 rue de l'Universite, Paris 7e".

\section{INDIA}

"..... the national data centre for oceanography has been started only recently under the Directorate of Indian Ocean Expedition (CSIR). The work regarding processing and assembling of data relating to the Indian work in the International Indian Ocean Expedition has also been taken up. This centre will eventually store data pertaining to the Indian Ocean Expedition in regard to all aspects 
both physico-chemical and biological and will closely collaborate with the World Data Centres A \& B with functions of a regional specialized data centre".

\section{UNITED KINGDOM}

"The United Kingdom designated national oceanographic data agency will be administered by the Hydrographer of the Navy, Oxgate Lane, Cricklewood, N.W.2.

The exchange of data will be limited initially to bathythermograph and physical oceanographic data and the information will be stored on 80 column ICT punched cards or in list form".

\section{UNITED STATES OF AMERICA}

The National Oceanographic Data Center, Washington, D.C. 20390

\section{Background}

For over one hundred years the United States has been acquiring and compiling oceanographic data . Many scientists have recognized the need for a central oceanographic data repository where data could be made available to all who needed them.

Based on a 1959 report of an Oceanographic Working Group, the Interagency Committee on Oceanography (ICO) recommended to the Federal Council for Science and Technology that the $\mathrm{Na}-$ tional Oceanographic Data Center be established, and that it be sponsored, financed, and its policies determined jointly by the Navy, the U.S. Coast and Geodetic Survey, the Weather Bureau, the Bureau of Commercial Fisheries, the National Science Foundation, and the Atomic Energy Commission. These recommendations were approved unanimously by the Federal Council on 28 June 1960 .

NODC was established as an administrative component of the Hydrographic Office (now U.S. Naval Oceanographic Office) on 1 November 1960 and the Interagency Agreement was signed by the Secretaries of Commerce, Navy, and Interior, the Director of the National Science Foundation, and the Chairman of the Atomic Energy Commission on 23 December 1960. The oceanographic data holdings of the U.S. Hydrographic Office, consisting of more than 20,000,000 machine punched cards, and a large number of variety of data logs, manuscript reports, and other forms were transferred to the NODC.

\section{Management}

NODC is managed in accordance with policies and procedures determined by an Interagency Advisory Board. This Board consists of representatives from each of the supporting agencies plus two representatives selected by the National
Academy of Sciences, and is probably one of the best informed groups on the Nation's oceanographic activities. In addition to the original (charter) sponsors mentioned above, the following have become sponsors of the Data Center: Coast Guard, Geological Survey, Coastal Engineering Research Center, and the Department of Health, Education, and Welfare.

\section{Operations}

The NODC Charter describes the areas of responsibility and functions of the Center. Primarily, the NODC is a central repository for the Nation's oceanographic data. Part of its mission is: to receive, compile, process, and preserve oceanographic data for rapid retrieval; establish procedures for ensuring that the accuracy and general quality of the incorporated data meet the criteria established by the Advisory Board; and to prepare data summaries, tabulations, and atlases showing annual, seasonal, or monthly oceanographic conditions.

\section{Services}

The data coverage embraces the total marine environment. At this time (September 1964), data holdings emphasize physical-chemical oceanography (hydrographic cast (station) data, bathythermograph data, surface currents). Systems are also being developed for retrieval of information (digital and non-digital) in marine biology and marine geology and pilot studies in these fields have been completed.

NODC was established to function as a service activity for the Nation's scientific community and for supplying their marine environmental data and information requirements. Data are available for public use free of charge at NODC, or copies of the data may be obtained atcost, or on exchange basis.

\section{Facilities}

The location of NODC within the District of Columbia is convenient to the many hotels, libraries, numerous governmental and private organizations, and several excellent universities in the Washington, D.C. area, as well as to the resources and collections of the U.S. National Museum . A National Aquarium is planned for the Washington, D.C. area in the near future. Nearby government agencies and facilities include the Library of Congress, the Bureau of Commercial Fisheries, Atomic Energy Commission, Weather Bureau, Naval Oceanographic Office, Navy Research Laboratory, Coast and Geodetic Survey, Coast Guard, Geological Survey, Public Health Service, Coastal Engineering Research Center, National Science Foundation, etc., also, the American University, Georgetown University, the George Washington University, and the University of Maryland are 
among the many institutions in the nearby area. A complete description of the Federal Government's information services, which includes many agencies in the Washingtor area, is given in the publication "Specialized Information Services in the United States", prepared by the National Science Foundation in November 1962.

Study rooms are available at NODC free of charge to the visiting scientist. Advance notification is requested to reserve a study room and it is advisable to indicate, in advance, the type of data and geographic areas of coverage required for study. Reproductions of existing data or machine listings or tabulations can be prepared at cost. Arrangements can be made to maintain a fund or working account at NODC from which work costs could be extracted. Reproductions are generally photostat, Ozalid, or Xerox processed.

The NODC 's A utomatic Data Processing (ADP) facilities include both Electric Accounting Machine (EAM) equipment and a high-speed computer system. The EAM equipment is located physically at NODC and consists of card punching machines, a card verifier, a sorter, a collator, a tabulator, and a card reproducing machine. The NODC is therefore well-equipped for performing "in house" the non-computational phases of machine data processing. All NODC computational work is scheduled daily on IBM 1401/7074 computer system housed at the U.S. Naval Oceanographic Office; the present NODC computer programmes have been written for this system. Also, the NODC maintains a library of machine programmes many of which are for use on other automatic data processing (ADP) equipment.

\section{Exchange}

Under its charter, the NODC is responsible for "acquiring by exchange, gift or purchase oceanographic data of scientific value from domestic or foreign sources". The NODC has undertaken exchange arrangements with 42 foreign nations, including member countries of the International Council for the Exploration of the Sea, and those participating in the International Indian Ocean Expedition.

Oceanographic data for international co-operative programmes and declared national programmes, are acquired by the NODC through the World Data Centre system. The latter system conducts data exchange under the "Guide to International Data Exchange through the World Data Centres (for the period 1960 onwards)", a publication of the Comite International de Geophysique, London, November 1963 . Data are also acquired by NODC through direct contact with governmental and private institutions in the United States and abroad.

Data may be exchanged with the NODC in two ways: (1) For contemporary data, the NODC will process contributed data, preferably coded on NODC forms according to NODC procedures, and provide final listing and/or duplicate punch cards in exchange for the data. Bathythermograph slides will be processed by NODC standard procedures and copies of the final BT prints will be provided to the contributor : Basic NODC data forms ( $\mathrm{log}$ sheets) and instructions are available on request. (2) For historical data or information (publications, reports, atlases, etc.) the NODC will usually exchange original or reproduced material in exchange for information of like kind.

Participants in exchange arrangements may delineate specific areas for which they require information. The NODC, on the other hand, accepts data or information from all oceans, seas, or estuaries.

NODC extends an invitation to all nations and to all institutions, corporations and individuals, both within and outside the United States, to exchange oceanographic data and information of all types.

\section{Address and location}

The mailing address for NODC is as follows: National Oceanographic Data Center, Washington, D.C. 20390 .

The Center is located in South East Washington near the Anacostia River. The Director 1s Dr. Woodrow C. Jacobs.

\section{Publications}

The NODC publishes a general series, a catalogue series, and a manual series. Those avallable are listed below.

\section{Additional data depositories}

International agencies located in the United States including marine environmental data in their holdings include the following components of the World Data Centre system:

World Data Center A, Oceanography

Washington, D.C., U.S.A. 20390

World Data Center A, Tsunamis; World Data Center A, Gravimetry; World Data Center A, Geomagnetism;

World Data Center A, Seismology. the address for all four is:

Geomagnetism Division,

U.S. Coast and Geodetic Survey,

Washington, D.C.,U.S.A. 20230.

World Data Center A, Meteorology

National Weather Records Center. Asheville, North Carolina, U.S.A. 28801.

The data in these centres are available to the National Oceanographic Data Centre.

Most oceanographic institutions in the United States retain, at least on a temporary basis, some oceanographic data collected for research purposes, pending analysis and release of the data. Data 
released by these institutions are available through the National Oceanographic Data Centre.

Publications (1)

General series

Publication G-1, Introduction to the National Oceanographic Data Centre, Price $\$ 0.40$

Publication G-2, Oceanographic Vessels of the World, volumes I and II, Price $\$ 4.50$ per volume

Publication G-3, EQUALANT I - Data Report, volumes I and II, Price $\$ 5.00$ per set

Publication G-4, Historical Analyses of Oceanographic Data in the Persian Gulf (in press)

Publication G-5, EQUALANT II - Data Report

Catalogue series

Publication C-1, Reference Sources for Oceanographic Station Data (out of print; revision in work)

Publication C-2, Catalogue of BT Data, World Wide (formerly SP-12, Part IIa, Inventory of BT Data, World Wide), Price \$0.40

Publication C-3, Catalogue of Oceanographic Data - North Atlantic Ocean (appeared originally as SP-12, Part IIb, Inventory of Oceanographic Data, North Atlantic Ocean; now out of print; revision in work)

Publication C-4, Films on Oceanography, Price $\$ 0.25$
Publication C-5, Computer Programmes in Oceanography (in press), Price $\$ 0.60$

Publication C-6, Inventory of Oceanographic Data in Indian Ocean (in work)

Publication C-7, Selective Reading List for Oceanology (in work)

Manual series

Publication M-1, Conversion Tables for use by the International Indian Ocean Expedition, Price $\$ 0.80$ (out of print)

Publication M-2, Processing Physical and Chemical Data from Oceanographic Stations (out of print; revision in work)

Publication M-3, Manual for BT Data Digitizing, Part I (in work)

Publication M-3, Analogue Processing Method for BT Data, Part II (in work)

Publication M-4, Manual for Coding Biological Data, provisional (in work)

Publication M-5, Manual for Coding Geological Data, provisional (in work)

Publication M-6, Manual for Coding and Keypunching Drift Bottle Data, provisional (in work)

(1) Normally, publications "in press" will be available in 60 days; for publications "in work" the time lapse is approximately 4 to 6 months; and "out of print" publications will be reprinted within 6 months or revised. 


\section{IGY World Data Centres}

The international exchange of data through World Data Centres was first organized during the IGY. This new form of international co-operation - exchange of data through WDCs - was found to be very effective. Instead of having to address themselves to many national organizations, scientists could recelve data necessary for scientific work directly from the WDCs. Thanks to the collection and exchange of data through WDCs, it became possible to investigate phenomena on a planetary scale and to study the interdisciplinary relationships among various phenomena.

Experfence has shown that the existing system of two universal centres, together with certain discipline centres, satisfies the demands of international exchange of geophysical data, creates optimum conditions for countries, and permits them to fulfil their obligations of exchange of geophysical data with minimum effort.

\section{CIG Guide for 1960-onwards}

At the end of IGY, the responsibility for the exchange of data through the WDCs was assigned by the International Council of Scientific Unions (ICSU) to the CIG. In response to the resolutions of various international scientific organizations $(e . g$. IUGG, URSI, IAU, COSPAR, SCAR, SCOR and IOC), the Comite International de Geophysique (CIG) has issued a revised "Guide to World Data Centres" based in large measure on the "Guide to IGY World Data Centres" adopted by CSAGI. In approving the "Guide", the CIG took into account the effective work of the CIG reporters and their working groups over a period of several years, and also the comments of the Geophysical Committees of participating countries and of international scientific organizations including COSPAR, SCAR, SCOR, the Intergovernmental Oceanographic Commission, and the Consultative Meeting of Representatives under the Antarctic Treaty, and others.
The main principles governing the responsibilities of the WDCs and the nature of data interchange are founded on the IGY "Guide" and the experience gained during the IGY. Both the general principles and the specific detalls of data exchange through the WDCs have been the subject of discussions and reports in many international scientific meetings, especially at the several meetings of CIG, and the CIG-IQSY Committee.

The revised "Guide" is based on two essential resolutions of CIG:

1. That the WDCs continue to collect, interchange, and make available to the scientific community data from the various geophysical disciplines on a permanent basis. The precise agreements on data to be exchanged should be reviewed periodically to ensure that these agreements continue to be meaningful in the light of rapidly changing scientific interests and findings.

2. The operation of the WDCs should be in accordance with the basic principles laid down by CSAGI, especially:

a. Each WDC must collect data according to the revised WDC Guide to be adopted by CIG on the basis of recommendations of the discipline specialists gathered by the reporters. b. Each WDC must agree to exchange data according to the conditions outlined in the Guide. In particular, the WDCs shall interchange among themselves by discipline in accordance with the Guide and at no charge. c. Each WDC is required to supply data (at a cost not to exceed the cost of reproduction) on request of scientists or scientific institutions.

d. Each WDC must be freely open to visitors and guest workers from any nation participating in the CIG programmes, and all data in the centres shall be accessible to such visitors and workers.

Types of centres

International exchange of geophysical data is 
effected through the World Data Centres, as in the IGY, and by means of the activities of certain specialized organizations:

(a) World Data Centres for collection and distribution of data. For each discipline, there are two or three such centres which operate according to the principles set forth in the Guide to WDCs.

i. World Data Center A, which consists of eleven subject-matter divisions and includes all disciplines.

ii. World Data Center B, which consists of two subject-matter divisions and includes all disciplines.

iii. World Data Center $\mathrm{C}$, which consists of several discipline centres in several nations.

(b) Centres for certain kinds of analysis and synthesis resulting in issuance of indices, certain bulletins of summary information, etc. There are two groups of such centres and provision is made for others as needed.

1. Permanent Services . Certain of the se have long ope rated and were also a part of the IGY World Data Centres. This is expected to continue as in the past; no change in relationships or procedures is involved. Moreover, data sent to the Permanent Services, where they are made available to all, unless specifically stated to the contrary, need not be sent in their primary form to the WDCs. The Permanent Services will send their bulletins, etc . to the WDCs; CIG , CIG national committees and all countries participatIng in IQSY; as appropriate to unions, associations and ICSU committees as well as their special committees corresponding to IQSY or other programmes for which data are exchanged through WDCs. In addition, WDCs shall provide the Permanent Services with their data as needed for the functions of the Permanent Services. CIG notes: that in each discipline the CIG Guide to WDCs must differentiate clearly between data flowing to WDCs and data flowing to Permanent Services;

that WDCs $A$ and $B$ may have data needed by the Permanent Services; such data shall be provided to the Permanent Services by the WDCs free of charge;

that in a few instances certain data collected by the Permanent Services are of interest to WDCs; and therefore requests that the institutions providing such data to the Permanent Services also provide copies of such data to the W-DCs. When Centers $\mathrm{A}, \mathrm{B}$ or $\mathrm{C}$ do not receive such material from the original institution, Centers A, B or C may request such material from the Permanent Service free of charge.

ii . Special world geophysical centres . During IGY, some of the WDCs compiled and published certain syntheses of scientific value; CIG encourages the furtherance of such activities in connexion with the WDCs. In addition, it may be desirable to establish additional centres of synthesis in connexion with new or existing Permanent Services, the WDCs or other appropriate organizations.

The World Data Centres are maintained at the expense of the countries which organize them. Special centres are maintained at the expense of the countries which establish them or, if they are located in a Permanent Service, at the expense of the Permanent Services. The countries which organize World Data Centres guarantee the condition for collection, storage, reproduction, distribution and safekeeping of materials, and also provide investigators the possibility to work personally with the material stored in the WDCs. The direct administration of WDCs is the responsibility of the appropriate national committee and scientific organization under which the WDC is established.

Every three years, each special world geophysical centre must present a report to the appropriate international scientific unions, associations, and committees about its work for the triennium, together with the proposed plan of work for the succeeding triennium. The unions, committees, and associations, having reviewed the reports and proposals of the centres, make their recommendations regarding the continuation, expansion, reduction, or termination of activities of the centres. These recommendations become effective after their approval by the CIG.

\section{CIG responsibilities}

Overall co-ordination of the activity of the WDCs and special world geophysical centres is the responsibility of the CIG . Committees and commissions established for carrying out international programmes (Committee for the International Years of the Quiet Sun and others) make recommendations to the CIG on questions of collection and exchange of data essential for accomplishing these programmes.

The data exchange arrangements through the WDCs should be reviewed and revised periodically to reflect the changing scientific problems being undertaken as part of international co-operative programmes. The decisions regarding changes in the list of materials collected in the WDCs, as well as initiation and termination of activities in the special world geophysical centres and changes in the programme of their work, are made by the CIG upon recommendation of international scientific unions and international scientific organizations after consultation with the corresponding national organizations. The international scientific unions, committees, and associations which assist the CIG in the organization of international exchange of data are indicated in the appropriate sections of the "Guide". The Guide to WDCs should be reviewed (and revised as necessary in accordance with the recommendations of the aforementioned groups) every two or three years. 
Functions and responsibilities of WDCs

The objects of establishing several IGY World Data Centres for collecting IG $Y$ observational data were: (1) to ensure against catastrophic destruction of a single centre, (2) to meet the geographical convenience of, and provide easy communication for, workers in different parts of the world.

WDCs conduct their operation at no expense to ICSU or the ICSU family of unions and committees.

Each WDC is responsible for: (1) endeavouring to collect a complete set of data in the field or discipline for which it is responsible, (2) the safekeeping of the incoming data, (3) correct copying and reproduction of data, maintaining adequate standards of clarity and durability, (4) supplying copies to other WDCs of data not received direct, (5) preparation of catalogues of all data in its charge, (6) making data in the WDCs available to the scientific community. In particular, WDCs are required to supply copies of material in the data centre to any scientific body or investigator in any country (for a cost not to exceed the cost of copying and postage) and, by appropriate arrangement, to enable scientists to work directly with the materials in the WDCs.

In addition the World Data Centres are called upon as follows:

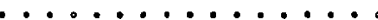

(b) To prepare and issue semi-annual catalogues of data.

(c) In general, to the extent possible, each WDC shall give to each contributor a body of data equivalent to that received; to the extent possible, the WDC may, upon request, give an equivalent volume of data from another discipline.

\section{Participation in data exchange through WDCs}

The international exchange of geophysical data through WDCs may be participated in by all countries of the world, both members of international scientific unions and other international organizations and non-members as well.

A country wishing to participate in the international exchange of data through the WDCs can so advise either a WDC or the CIG. In so doing, the country reports: the kind of data that will be sent to one or another of the WDCs; the organization that will be responsible for communication with the centres; and from which centre it wishes to receive requests for transmittal of data in the event of special events. This information is then distributed either by the WDCs or the CIG to all interested centres and national committees.

Scientific organizations and individual scientists may order materials from the centres directly or through their national organization responsible for communication with the WDCs. In those cases in which materials are ordered directly, it is desirable for the centres to inform the organization responsible in that country for communication with the WDCs what materials were sent to other organizations in that country. For the purpose of assuring to scientists greater accessibility of materials from the centre, it is recommended that materials received from the centres be concentrated in one or in several scientific organizations of the country from which they can be obtained for work by any interested scientist of the country.

The organizations which are responsible for communication with the WDCs verify whether all data sent by them are included in the WDC catalogues and, in the event of discovery of some sort of omission in the material sent by them, they so inform the appropriate centres and take measures to search for and complete the collection of the missing materials.

The national organization responsible for communication with the WDCs as well as any scientific organizations and individual scientists may borrow from the WDCs any puilication for which duplicates are available in the centre for temporary use for a period not to exceed one month, not including time of transmittal. If it is desired, a microfilm copy of the publication can be made for a cost not to exceed the cost of copying and transmittal.

The transmittal of data and publications to the WDCs and analytical centres is made within the period of time and according to formats indicated in the appropriate sections of the "Guide".

\section{General data exchange agreements}

\section{Transmittal to WDCs}

(a) The basic recommendation is that one copy of data shall be sent to each relevant WDC, if practicable.

(b) Alternatively, enough copies may be sent to one WDC for forwarding to all other WDC;

(c) or, lastly, one copy may be sent to one WDC which will then make copies for the other WDCs.

The selection of the WDCs to which to send data is the responsibility of the station or of the Participating Committee.

The data specified for exchange are, in general, closely related to international scientific programmes. In addition to the data specified in the Guide, scientists, institutions or participating committees are asked to send to the WDCs special publications related to these programmes, i.e. articles not available in the widely circulated geophysical journals, maps, atlases, reports, etc. Three copies should be sent to each WDC or six copies to one WDC for forwarding to the other WDCs 。

In the event that a country sends data to one of the WDCs only, the country should notify the other WDC (for example, by means of sending a copy of the transmittal letter).

Quality of data. WDCs are not generally responsible for accuracy. of data in their possession. 
In some disciplines (for example, solar activity), the WDCs may be requested by the CIG reporter to monitor data.

Exchange among WDCs. Each WDC will provide within two months of receipt, and on a freeexchange basis, copies of all incoming data to any other WDCs (for the discipline) which have not received those data.

Catalogues. Catalogues of data received by the WDCs will be issued at six-monthly intervals. Catalogues are sent free to other WDCs, special world geophysical centres, organizations responsible for communication with the WDC and to addresses supplied by the geophysical committees of the countries participating in the exchange.

Catalogues of newly received publications, data, and materials are prepared in accordance with established formats for each discipline. The names of publications are given in the language of the original and, if necessary, in translation into one of the widely known European languages. Information about the data received by the WDC is given in the catalogue by discipline, country and station. For each station the following is given: station name, kind of data, and period for which data were received.
Use of data in WDCs. All WDCs shall satisfy promptly, in any case within three months, the demands of scientific bodies or investigators in any country for copies of material, or extracts thereof. The fee charged should not exceed the cost of copying plus postage. (Exceptions to the time schedule may be made when the WDC must give priority to requirements of CIG and Participating Committees).

Each WDC shall be freely open to visitors and guest workers from any country participating in the CIG programmes, and all data in the centres shall be accessible to such visitors and workers.

Acknowledgement. When data are supplied by a WDC in response to a request, the WDC shall transmit them with a letter stating the location of the observations and the name and address of the investigator responsible for securing the data. The letter shall contain a request to the person receiving the data to respect the usual rights of the investigator.

For all disciplines the recipient of data shall be requested to make appropriate acknowledgement to the original investigator, and the WDC in any subsequent publication involving the data. 


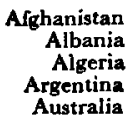

Austria

Austria
Belgium

Bolivia

Brazil

Bulgaria

Burma

Cambodia

Canada

Chile

China

Colombia

Congo

Costa Rica

Cuba

Cyprus

Czechoslovakis

Denmark

Dominican Republic

Ecuador

El Salvador

Ethiopia

Finland

French West Indie

Germany (Fed. Rep.)

Ghana

Greece

Hait

Hondura

Hong Kong

Hungary

India

Indonesia

Ira

Iraq
Ireland

Ireland

Italy

Ivory Coast

Jamaica

Jamaica

Jordan

Kenya

Korea

Lebanon

Liberia
Libya

Liechtenstein

Luxembour

Madagascar
Panuzai, Press Department, Royal Afghan Minintry of Education, Kanuz.

N. Sh. Botimeve Naim Frasheri, TiRanA.

Institut pedagogique national, 11 , rue Zàatcha, Alosr.

Editarial Sudamericana S A Al,

Tradco Agencies, 109 Swanston St, G.P.O. Box 2324 V, Mrlsourne C.I (Victoria).; United Nations Association of Australia, Victorian Division, Bth Floor, McEwan House, 943 Little Collins St., Melbourmz C. (Victoria).

Verlag Georg Fromme \& Co., Spengerganse 39, WiEN 5.

Editions 'Labor', 342, rue Royale, BRUXRLles 3; N.V. Standaard Boekhandel, Belgiëlei 151 , ANTwerpre. For 'The Courier' and slides: Louid de Lannoy, 'Le Courtier de l'Unesco', 1 r2, rue du Tröne, Bruxelles 5. Libreria Universitaria, Universidad San Francisco Xavier, apartado 212, Sucre; Libreria Banet, Loayza i 18 , casilla 1057, LA PAZ.

Fundação Getúlio Vargas, praia de Botafogo 186, Rio de Janeiro, GB ZC-02.

Raznoiznos, I Tzar Assen, SoruA.

Burma Translation Society, 36 I Prome Road, Ravaoon,

Librarie Albert Portail, I4, avenue Boulloche, Phrom-Penh.

The Queen's Printer, Ortawa (Ont.).

Lake House Bookshop, Sir Chittampalam Gardiner Mawata, P.O. Box 244, Colompo 2.

Editorial Universitaria S.A. avenida B. O'Higgins 1058, casilla 10220, SANTIAoo

For' The Courier': Comision Nacional de la Unesco en Chile, alameda B. O'Higgins 16 I1, 3.or piso, SANTuco.

For 'The Courier': Comision Nacional de la Unesco en Chile, alameda B. O'Higgins 1611, $3^{\circ{ }^{\circ}}$ piso,

Librería Buchholz Galería, avenida Jiménez de Ouesad 8-40, Booot ; ; Ediciones Tercer Mundo, apartado Libreria Buchholz Galeria, avenjda Jiménez de Quesada 8-40, Boootর; Ediciones Tercer Mundo, apartado aéreo 4817, Bogotá; Comité Regional de la Unesco, Universidad Industrial de Santander, Bucaramanoa; Distrilibros Ltd., Pio Alvonso García, calle Don Sancho $n .^{88}: 36-119$ Y $36-125$, Cartagena ; J. Germán Rodriguez N., oficina 201, Edificio Banco de Bogotá, apartado nacional 83, GrRnroot; Escuela Interamericana
de Bibliotecologia, Universidad de Antioquia, Mrdeluis; Libreria Univergitaria, Universidad Pedagógica de Colombia, TuNJA.

La Librairie, Institut politique congolais, B.P. 2307, LÉopoldvrLle.

Trejos Hermanos, S.A., apartado 1313, SAN Jose.

For 'The Courier': Carlos Valerin Sáenz \& Co. Ltda., 'El Palacio de la Revistas', apartado 1924, SAN José.

Cubartimpex, apartado postal 6540, LA HАBANA

Cyprus National Youth Council, P.O. Box 539, Nicosua.

SNTL, Spalena 51, Praha I (Permanent display); Zahranicni Jiteratura, Bilkova 4, Prahs I.

Ejnar Munksgaard Lid., Prags Boulevard 47, Köbenhave S.

Libreria Dominicana, Mercedes 40 apal tado de correos 656 , SANTO DOMiNGo.

Casa de la Cultura Ecuatoriana, Núcleo del Guayas, Pedro Moncayo y 9 de Octubre, casilla de correo 3542, GuYyouIL.

Libreria Cultural Salvadorena, SAN SALvaror.

International Prees Agency, P.O. Box 120, Addrs Ababa.

Akateeminen Kirjakauppa, 2 Keskuskatu, Heısinkı.

Libsairie de l'Unesco, place de Fontenoy, PAR1s-7 ${ }^{\circ}$. CCP $12398-4^{8}$

Librairie J. Bocage, rue Lavoir, B.P. 208, Fort-DE-France (Martinique).

R. Oldenbourg Verlag, Unesco-Vertrieb für Deutschland, Rosenheimerstrasse 145, MüncheN 8.

Methodist Bool: Depot Ltd., Atlantic House, Commercial Street, P.O. Box 100, CAPE CoAst.

Librairie H. Kaufimann, 28, rue du Stade, Athènes.

Comisión Nacional de la Unesco, 6. ${ }^{\mathrm{a}}$ Calle 9.27 , zona 1, Guatemula.

Librairie 'A la Garavelle', 36, nue Roux, B.P. II 1 , Port-Au-Prince.

Librería Cultural, apartado postal 568 , Teovcionlpa D.c.

Swindon Book Co., 64 Nathan Road, Kowloon.

Kultura, P.O. Box I49, BudAPEsT 62.

Snaebjörn Jonsson \& Co., H.F., Hafnarstraeti 9, REYKJAYre.

Orient Longmans Ltd.: if Chittaranjan Avenue, CALcuTta i3; Nicol Road, Ballard Estate, BomBAy I;

Grient Longmans Ltd.: 17 Chittaranjan Avenue, CalcutTa 13; Nicol Road, Ballard Estate, Bompay I; Gunfoundry Road, Hyde

Box 386, New Delw1 I.

Oxford Book \& Stationery Co.: 17 Park Street, Calcutia 16; and Scindia House, New DelHs.

P. N. Fadjar Bhakti, Djalan Nusantara 22, DJAkARTA.

Commission nationale iranienne pour l'Unesco, avenue du Muste, TÉthass.

McKenzie's Bookshop, Al-Rashid Street, BAOHDAD.

The National Press, 2 Wellington Road, Ballsbridge, Dubuis.

Blumstein's Bookstores: 35 Allenby Road and 48 Nahlat Benjamin Street, Tel Avrv.

Libreria Commissionaria Sansoni S.p.A., via Lamarmora 45, casella postale 552, Furznze; Libreria Internazionale Rizzoli, Galeria Colonna, Largo Chigi, Roma; Libreria Zanichelli, Portici del Pavaglione,

Bologna; Hoepli, via Ulrico Hoepli 5, Mrlano; Librairie française, piazza Castello 9, Torino.

Centre d'édition et de difision africaines, boite postale 4541, Abmjay Plateav.

Sangster's Book Room, 91 Harbour Street, Krngston.

Maruzen Co. Ltd., 6 Tori-Nichome, Nihbonbashi, P.O. Box 6o5, Tokyo Central, Toxyo.

Joseph I. Bahous \& Co., Dar-ul-Kutub, Salt Road, P.O. Box 66, Aunan.

ESA Bookshop, P.O. Box 30167 , NAJROBI

Korean National Commission for Unesco, P.O. Box Central 64, Seour

Librairie Dar Al-Maaref Liban, S.A.L., immeuble Esseily, $3^{\circ}$ étage, place Riad El Solh, B.P. 2320, BeYroutr.

Cole \& Yancy Bookshops Lid., P.O. Box 286, MonRovi.

Orient Bookshop, P.O. Box 255, TRIPOLI.

Eurocan Trust Reg., P.O.B. 124, SchaAN.

Librairie Paul Bruck, 22 Grande-Rue, Luxemboura.

Commission nationale de la République malgache, Ministère de l'Éducation nationale, TaNanarive.

For 'The Courier': Service des cuvres post et péri-scolaires, Ministère de l'Education nationale, TANANARIve. 


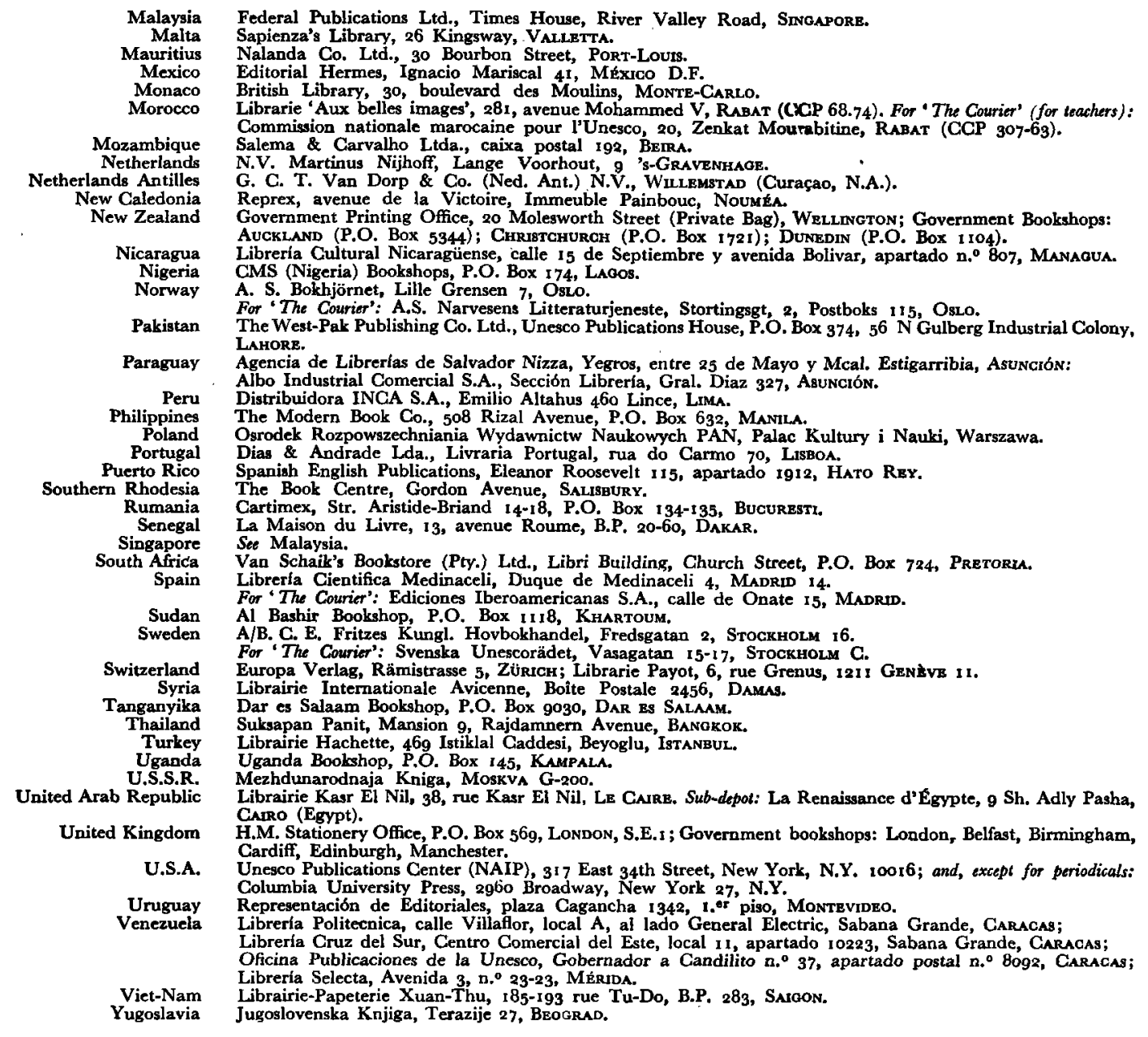

